\title{
LITERASI SAHAM PADA MAHASISWA STIESIA SURABAYA
}

\section{Rizal Christian Mahendra*}

\begin{abstract}
Abstrak
STIESIA Surabaya sebagai kampus ekonomi mendukung kegiatan investasi saham dengan mendirikan Galeri Investasi Bursa Efek Indonesia. Dengan kenaikan jumlah investor setiap tahunnya, Galeri Investasi Bursa Efek Indonesia menyelenggarakan kegiatan literasi saham yang bekerja sama dengan Perpustakaan STIESIA Surabaya. Tulisan ini bertujuan membahas mengenai bagaimana literasi saham pada mahasiswa STIESIA Surabaya, bagaimana kegiatan investasi saham mampu meningkatkan kesejahteraan investor, serta peran Perpustakaan STIESIA dalam literasi saham. Tulisan ini tidak menggunakan metode penelitian, namun menggunakan kajian literatur textbook, website dan artikel. Adapun hasil dari tulisan ini adalah Perpustakaan STIESIA memiliki peran dalam literasi saham di STIESIA Surabaya seperti melakukan bimbingan penelusuran informasi yang berkaitan dengan saham, menyediakan bahan pustaka yang berkenaan, serta sebagai media promosi pemanfaatan Galeri Investasi Bursa Efek Indonesia. Diharapkan tulisan ini mampu memberikan inovasi baru dalam dunia perpustakaan untuk melakukan kerja sama dengan unit kerja yang lain.
\end{abstract}

Keywords: Literasi, Saham, Perpustakaan, Kesejahteraan

\section{PENDAHULUAN}

Saham merupakan surat berharga yang menunjukkan bagian kepemilikan atas suatu perusahaan. Pentingnya investasi saham telah dirasakan oleh masyarakat. Hal ini dapat dilihat dari meningkatnya jumlah investor saham tiap tahunnya seperti yang dilansir pada portal berita bahwa PT. Bursa Efek Indonesia (BEI) mencatat jumlah investor hingga akhir September 2017 sebanyak 1,1 juta Single Investor Identification (SID). Terdiri dari $500 \mathrm{ribu}$ investor dan 600 ribu investor saham (www.economy. okezone.com). Dalam situs IDX disebutkan bahwa investasi saham atau di sebut sebagai investor saham dirasa penting karena mempunyai manfaat diantaranya mendapatkan dividen yaitu keuntungan dari sebagian laba perusahaan atas saham yang dimilikinya dan mendapatkan capital gain yaitu keuntungan dari harga jual saham apabila perusahaan berkembang.

Untuk memberikan edukasi yang benar tentang pasar modal dan investasi saham kepada mahasiswa, maka STIESIA sebagai perguruan tinggi bidang ilmu ekonomi telah mendirikan Galeri Investasi Bursa Efek Indonesia. Sebagai salah satu pusat sumber informasi,

\footnotetext{
* Pustakawan Sekolah Tinggi Ilmu Ekonomi Indonesia (STIESIA) Surabaya
} Email: rizalchristianm@gmail.com perpustakaan mempunyai akses yang strategis dalam mendukung keberhasilan program pendidikan dan pembelajaran masyarakat civitas akademika dalam upaya mencerdaskan pengguna perpustakaan pada khususnya dan masyarakat pada umumnya. Adanya Galeri Investasi Bursa Efek Indonesia STIESIA menjadikan peran dan fungsi penting perpustakaan dalam mewujudkan keberhasilan program pendidikan sekaligus sebagai upaya peningkatan kualitas civitas akademikanya dalam mengembangkan pengetahuan dan keahliannya dibidang pasar modal dan investasi saham.

Penggalian informasi dari berbagai sumber untuk memperkaya wawasan tentang suatu bidang ilmu adalah aktivitas utama civitas akademika perguruan tinggi. Sebagai salah satu pusat sumber informasi, perpustakaan menyediakan seperangkat sarana dan prasarana baik software maupun hardware untuk dimanfaatkan dalam menggali sumber-sumber informasi yang dibutuhkan sivitas akademika khususnya sumber informasi tentang pengetahuan pasar modal dan investasi saham sebagaimana berkaitan dengan program pembelajaran yang dijalankan di Galeri Investasi Bursa Efek Indonesia STIESIA. Melalui kegiatan literasi saham di perpustakaan, 
seperti pengelolaan, pelayanan, penyediaan (akses) informasi, dan bimbingan penelusuran, diharapkan mahasiswa dan sivitas akademika lainnya dapat memanfaatkan semaksimal mungkin pengetahuannya untuk menunjang proses pembelajarannya di Galeri Investasi Bursa Efek Indonesia STIESIA. Melalui berbagai kegiatan pengelolaan dan pelayanan yang tersedia di perpustakaan tersebut, maka perpustakaan dapat mengoptimalkan peran dan fungsi pentingnya dalam mewujudkan keberhasilan pendidikan civitas akademikanya.

Galeri Investasi Bursa Efek Indonesia STIESIA didirikan pada tahun 2012 dengan tujuan untuk memasyarakatkan pasar modal sejak usia muda, salah satunya untuk mengenalkan pasar modal kepada lingkungan anak-anak Sekolah Menengah Atas. Kegiatan yang dilakukan yaitu dengan mengadakan kelas kecil pengenalan saham atau sosialisasi edukasi dengan target dalam satu tahun sebanyak 3 kali kegiatan. Kegiatan tersebut diikuti oleh mahasiswa STIESIA, para dosen serta untuk umum masyarakat yang ingin belajar tentang saham. Sebagai perguruan tinggi bidang ilmu ekonomi yang dilengkapi sarana Galeri Investasi Bursa Efek Indonesia, maka kegiatan literasi saham diharapkan dapat memberikan manfaat yang optimal bagi mahasiswa dan civitas akademika, sehingga penyebaran informasi pasar modal tepat sasaran serta dapat memberikan manfaat bagi pihak-pihak lain dan masyarakat umum di daerah dan sekitar kampus STIESIA baik untuk kepentingan sosialisasi dan pendidikan/edukasi pasar modal maupun untuk kepentingan ekonomis atau alternatif investasi.

Adapun latar belakang penulis mengambil tema ini adalah karena belum ada kajian sebelumnya mengenai peran perpustakaan dalam literasi saham yang bekerja sama dengan Galeri Investasi Bursa Efek Indonesia STIESIA Surabaya. Selain itu Galeri Investasi Bursa Efek Indonesia di STIESIA Surabaya mempunyai keunggulan yang berbeda dari kampus lainnya yaitu mempunyai pengelola khusus yang ditugaskan kepala galeri untuk mengoperasionalkan data. Bagi mahasiswa keuangan, maka pihak BES mempunyai persyaratan yaitu menyerahkan skripsi ke galeri yang bisa dimanfaatkan untuk para pengguna. Tidak hanya itu, Galeri Bursa Efek Indonesia STIESIA melakukan penjualan data pada mahasiswa maupun dosen, penjualan data tersebut berupa laporan keuangan perusahaan.

Adapun rumusan masalah dalam tulisan ini yaitu Bagaimanakah literasi saham pada mahasiswa STIESIA Surabaya?

\section{TINJAUAN LITERATUR}

\section{Literasi}

Literasi adalah kemampuan sesorang dalam memahami, menelusuri dan menggunakan serta mengolah suatu informasi pengetahuan Dalam kamus besar bahasa indonesia dijelaskan Literasi adalah kemampuan menulis dan membaca, pengetahuan atau keterampilan dalam bidang atau aktivitas tertentu dan kemampuan individu dalam mengolah informasi pengetahuan untuk kecakapan hidup.

UNESCO (2008) menyebutkan pengertian literasi adalah seseorang yang dapat memahami keduanya antara membaca dan menulis untuk digunakan dalam kegiatan sehari-hari. Ada empat cara dalam mengetahui apa itu literasi yang disebutkan disini yaitu:

- Literasi adalah kemampuan termasuk disini adalah kemampuan membaca menulis berkomunikasi; keterampilan berhitung; dan serta kemampuan dalam mengakses pengetahuan dan informasi. Definisi umum yang sering digunakan oleh banyak kalangan.

- Literacy as applied, practiced and situated sebuah cara untuk dipraktikkan dalam beberapa situasi dijelaskan disini bagaimana seseorang dapat menggunakan kemampuan literasinya dalam kehidupan sosial. Mulai berargumen memberikan gagasan memecahkan suatu masalah, mencari informasi mendapatkan dan memahami informasi. Dan banyak lainnya.

- Literacy as a learning process setiap individu yang melakukan proses pembelajaran tentunya melibatkan kegitan membaca dan menulis, maka dari itu literasi bisa disebut juga dengan proses pembelajaran.

- Literacy as text Bhola 1994 dalam UNESCO 2008 menyebutkan alamiahnya tulisan itu adalah produk dari literasi seseorang dan nantinya akan digunakan kembali sebagai bahan literasi individu lainnya.

\section{Saham}

Menurut Darmadji dan Fakhruddin (2011), saham (stock) merupakan tanda penyertaan atau kepemilikan seseorang atau badan dalam suatu perusahaan atau perseroan terbatas. Sedangkan, Sunariyah (2011), menjelaskan bahwa saham adalah surat berharga sebagai bukti penyertaan atau pemilikan individu maupun institusi yang dikeluarkan oleh sebuah perusahaan yang berbentuk Perseroan Terbatas (PT). Saham menyatakan bahwa pemilik saham tersebut adalah juga pemilik sebagian dari perusahaan tersebut. 
Jadi saham adalah surat berharga yang diperdagangkan di pasar modal yang dikeluarkan oleh perusahaan yang berbentuk Perseroan Terbatas (PT), dimana saham tersebut menyatakan bahwa pemilik saham tersebut adalah juga pemilik sebagian dari perusahaan tersebut. Oleh karena itu, saham dapat pula dikatakan sebagai tanda penyertaan modal. Imbalan atas modal yang disertakan pada perusahaan tersebut, investor berhak atas dividen atau yang lainnya yang proporsinya sesuai dengan modal yang disetor pada perusahaan.

Saham merupakan salah satu jenis investasi yang semakin banyak diminati karena keuntungannya yang besar. Investasi ini merupakan jenis investasi yang memiliki risiko besar namun juga pengembalian yang tinggi. Membeli saham sama dengan membeli sebagian kepemilikan dari suatu perusahaan yang sahamnya kita beli (https: //dosenekonomi. com/bisnis /investasi/ keuntungan-investasi-saham). Investasi merupakan penanaman modal berupa uang atau barang berharga lainnya dengan tujuan untuk melipatgandakan kekayaannya. Selain untuk menambah kekayaan, investasi juga bermanfaat untuk meminimalkan tekanan inflasi. Dengan berinvestasi, nilai kekayaan yang dimiliki seseorang dapat lebih menyesuaikan dengan nilai inflasi (https://dosenekonomi.com/bisnis/investasi/instrumeninvestasi).

Beberapa keuntungan investasi saham, diantaranya adalah 1) Dividen tunai. Dividen adalah keuntungan perusahaan selama periode tertentu yang dibagikan kepada setiap pemegang saham masing-masing menurut jumlah lembar kepemilikan sahamnya dalam bentuk nilai tunai, 2) Saham bonus. Saham bonus adalah pembagian saham kepada para pemegang saham berdasarkan jumlah lembar yang dimilikinya dalam bentuk saham. Dengan membagikan saham bonus, perusahaan tidak perlu mengurangi jumlah kas yang dimilikinya, karena keuntungan yang dibagikan bukan dalam bentuk tunai melainkan dalam bentuk saham, 3) Bonus saham. Pembagian bonus saham ini biasanya ditentukan berdasarkan jumlah kepemilikan saham seorang pemegang saham. Misalnya A memiliki 10 lot saham perusahaan $\mathrm{X}$ dan perusahaan $\mathrm{X}$ telah menetapkan satu saham bonus untuk kepemilikan setiap 10 lot, maka A berhak mendapatkan tambahan satu lot saham sebagai saham bonusnya. Pada saat baru dibagikan, nilai 10 lot dan 11 lot saham perusahaan X adalah sama. Keuntungan yang didapat pemegang saham dengan saham bonus baru dapat dirasakan dalam jangka panjang, yaitu saat harga saham tersebut naik, 4) Capital gain. Capital gain merupakan keuntungan dari selisih harga beli dan harga jual saham yang diperdagangkan. Memperoleh keuntungan dari capital gain seringkali merupakan tujuan dari investor jangka pendek yang melakukan jual beli hanya dalam hitungan hari, namun juga tidak menutup kemungkinan untuk investor jangka panjang juga melakukannya karena capital gain dapat diperoleh dalam jangka waktu kepemilikan saham yang tidak ditentukan (https://dosenekonomi.com/bisnis/investasi/ keuntungan-investasi-saham).

\section{Literasi Saham}

Jelley, 1958 (dalam Remund, 2010) menyebutkan definisi paling dasar dari literasi saham adalah kompetensi seseorang untuk mengelola saham. Dan menurut Widayati (2012) menjelaskan bahwa literasi saham terjadi ketika individu memiliki beberapa keahlian dan kemampuan yang memengaruhi seseorang memanfaatkan sumber daya yang ada untuk mencapai suatu tujuan.

\section{Kesejahteraan}

Pada kamus besar Bahasa Indonesia kesejahteraan berasal dari kata sejahtera yang memiliki makna keamanan, keselamatan, dan ketentraman PSNACET menjelaskan Kesejahteraan adalah pikiran yang mencerminkan kebahagiaan dan kepuasan manusia, kesejahteraan individu adalah total dari kepuasan yang dialami oleh individu dan kesejahteraan sosial adalah jumlah dari kesejahteraan masing-masing individu. Jika dilihat pada Undang-Undang Nomor 11 Tahun 2009 Kesejahteraan Sosial memiliki makna kondisi terpenuhinya kebutuhan material, spiritual, dan sosial warga negara agar dapat hidup layak dan mampu mengembangkan diri, sehingga dapat melaksanakan fungsi sosialnya. Besley (2002) menyebutkan kesejahteraan ekonomi adalah dasar untuk menilai pencapaian pasar dan pembuatan kebijakan dalam mengalokasikan sumber daya.

Adapun dalam tulisan ini kesejahteraan yang dimaksud adalah berinvestasi saham mampu menambah keuangan bagi para mahasiswa, yang dimana dapat mereka gunakan sebagai tambahan uang saku, berbisnis, hingga membiayai perkuliahan mereka.

\section{PEMBAHASAN}

\section{Literasi Saham di Galeri Investasi Bursa Efek Indonesia}

GALERI INVESTASI Bursa Efek Indonesia (BEI) dimaksudkan untuk mengenalkan Pasar Modal sejak dini 
pada dunia akademis. Pendirian GALERI INVESTASI BEI berkonsep 3 in 1 (kerjasama antara BEI, Perguruan Tinggi dan Perusahaan Sekuritas) sehingga diharapkan civitas akademika tidak hanya mengenal Pasar Modal dari sisi teori saja akan tetapi dapat langsung melakukan praktiknya. Peran GALERI INVESTASI BEI sebagai One stop student activities pasar modal di dunia akademisi merupakan salah satu sarana pembelajaran yang dapat menjadi sebuah kekuatan untuk mencerdaskan bangsa. Kedepannya melalui laboratorium pasar modal yang menyediakan real time data untuk belajar menganalisa aktivitas perdagangan saham, diharapkan dapat menjadi jembatan menuju penguasaan ilmu pengetahuan beserta praktiknya di Pasar Modal, sehingga perguruan tinggi dapat menghasilkan, masyarakat akademisi yang memahami teori beserta praktiknya.

Mahasiswa tidak hanya melakukan teori melalui kelas perkuliahan tetapi mempraktikkan ilmunya di Galeri Investasi BEI dengan cara praktek setiap hari rabu dengan Jumlah 4-6 Mahasiswa dan sekarang galeri Investasi BEI STIESIA dapat dorongan dari dosen kepada mahasiswa yang mengikuti perkuliahan sesuai dengan teori mengenai agar pasar modal terutama mengenai saham dipraktikkan di galeri BEI Investasi BEI STIESIA dengan Jumlah mahasiswa 80 mahasiswa. Literasi yang dilakukan dengan menjelaskan mengenai pasar modal yang dimana agar mengetahui pasar modal mengenai saham yang dimana para mahasiswa mengetahui cara membaca trading saham dan step-step cara mengoperasikan trading saham. Dengan banyaknya minat dari mahasiswa STIESIA yang sudah lihai dalam praktek terutamanya pasar modal ada ketertarikan juga yang ingin bekerja di lingkungan pasar modal dan mahasiswa STIESIA juga pernah mendapatkan juara 2 sebagai duta saham tahun 2017.
Gambar 1 merupakan salah satu contoh mahasiswa yang membeli saham perusahaan dengan Kode Cleo membeli 1 Lot Saham (100 Lembar) harga per-saham Rp.820 dengan total pembelian Rp82.000,dari pembelian saham mendapatkan keuntungan saham sebesar $46,34 \%$ (38.000) jadi total yang didapatkan dari membeli saham Rp. 120.000 .

Gambar 2 merupakan mahasiswa lainnya yang melakukan investasi saham. Mahasiswa tersebut membeli saham perusahaan dengan Kode BAPA membeli 5 Lot Saham (500 Lembar) harga per-saham Rp.158 dengan total pembelian Rp65.500,dari pembelian saham mendapatkan keuntungan saham sebesar 46,34\% (13.500) jadi total yang didapatkan dari membeli saham Rp.79.000.

Dengan berinvestasi saham, mahasiswa STIESIA Surabaya mendapatkan keuntungan yang dapat digunakan untuk membayar SPP dan Uang Jajan sehari-hari yang didapat menguntungkan dari praktek main Saham di Galeri BEI STIESIA surabaya.

\section{Peran Perpustakaan STIESIA Surabaya dalam Literasi Saham}

Dalam melakukan literasi saham, Perpustakaan STIESIA bekerjasama dengan Galeri Investasi Bursa Efek Indonesia STIESIA. Adapun peran Perpustakaan STIESIA Surabaya dalam literasi saham yaitu:

1. Melakukan Bimbingan Penelusuran yang Berkaitan dengan Saham antara lain:

a. Mengisi formulir pembukaan rekening efek Mahasiswa/nasabah yang berminat dan berkenan untuk berinvestasi saham perpustakaan berperan dalam membantu menyediakan form pengisian biodata untuk awal pembukaan rekening efek dan rekening dana. Rekening dana yaitu rekening yang

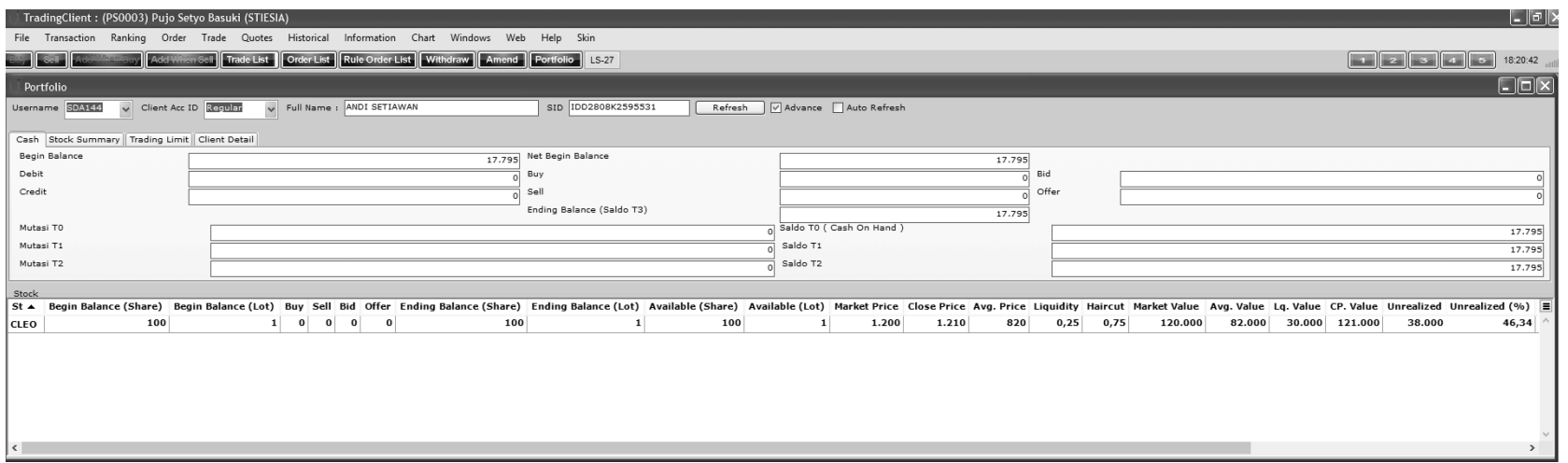

Gambar 1. Contoh mahasiswa yang membeli saham perusahaan dengan Kode Cleo 


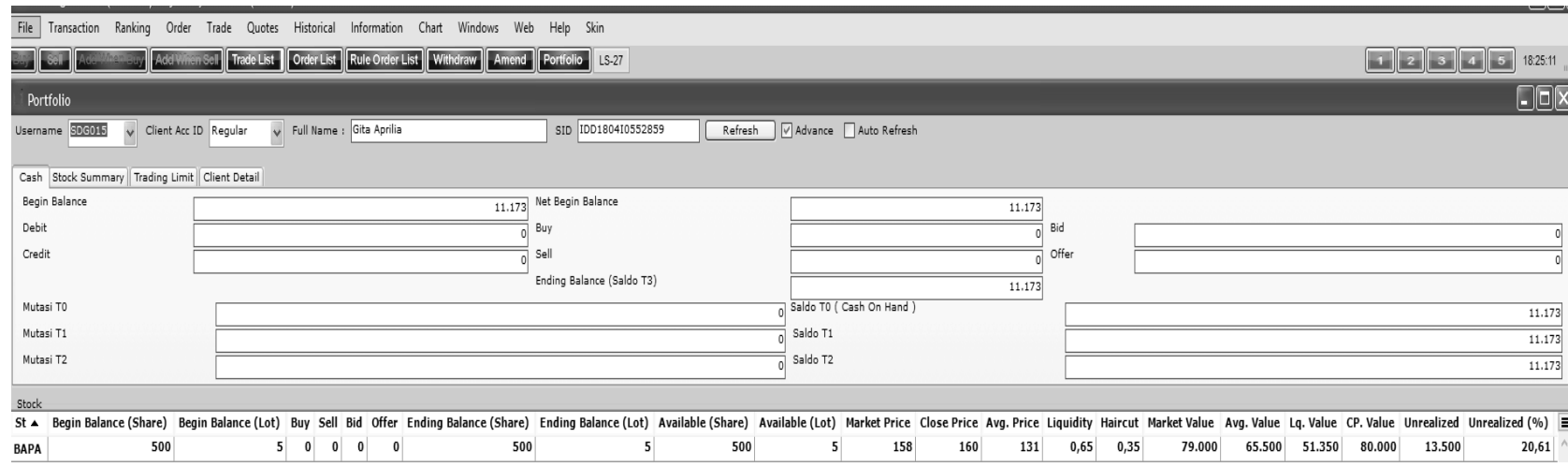

Gambar 2. Mahasiswa yang melakukan investasi saham

memuat catatan tentang masuk dan keluarnya uang nasabah dan saldo uang nasabah Setiap saat. broker yang jujur akan memberikan bunga harian atas saldo kredit uang nasabah sedangkan saldo debet nasabah juga dikenakan bunga. Rekening efek yaitu rekening yang memuat saldo efek milik nasabah yang disimpan di broker efek.

b. Menyerahkan Foto copy KTP beserta NPWP Mahasiswa/nasabah yang selesai mengisi data form wajib melampirkan selembar foto copy KTP dan NPWP sebagai data diri nasabah untuk melakukan investasi saham

c. Menyerahkan uang sebesar 100 ribu rupiah untuk pembukaan investasi. Pembukaan setoran awal dalam investasi saham minimal Rp.100.000,00 bisa lebih tanpa adanya paksaan dari perpustakaan maupun pihak galeri BEI

d. Nasabah/mahasiswa mendapatkan nomor RDI dari reliance apabila semua prosedur persyaratan sudah di penuhi oleh nasabah untuk mulai berinvestasi saham.

2. Menyediakan koleksi atau bahan pustaka yang berkaitan tentang investasi saham

a. IDX Factbook adalah sumber informasi tanpa tandingan, Buku yang diterbitkan oleh Bursa Efek Indonesia bisa di unduh gratis di halaman Factbook situs IDX dab berisi daftar emiten dengan kapitalisasi terbesar, transaksi terbesar, kenaikan/penurunan terbesar, dan juga data akhir tiap emiten, termasuk EPS, PER, book value, kapitalisasi pasar, net income, dan data keuangan dasar penting lainnya. b. ICMD singkatan dari Indonesia Capital Market Directory. Berisi tentang ringkasan kinerja perusahaan yang terdaftar di Bursa Efek Indonesia (BEI)

c. pengertian dari laporan bulanan setiap perusahaaan yang terdaftar di perusahaan BEI / IDX

d. Web IDX pengertian penelusuran tentang laporan keuangan suatu perusahaan yang terdaftar di BEI atau bisa mengakses lewat google dengan situs www.idx.co.id

3. Mengarahkan Praktek ke Galeri BES

a. Mengikuti kelas mengenai saham yang diadakan oleh petugas galeri BES.

Mahasiswa yang belum mengerti atau paham tentang berinvestasi saham petugas galeri BES membuka kelas khusus untuk memberikan pengarahan informasi tentang saham atau pasar modal yang diadakan setiap hari rabu pagi sampai sore.

b. Mendatangkan Marketing Reliance.

Pihak galeri BEI bekerja sama dengan marketing reliance apabila ada nasabah yang ingin mengikuti kelas khusus tentang informasi dan penjelasan tentang investasi saham.

\section{PENUTUP}

Pentingnya saham mulai dirasakan oleh masyarakat Indonesia, hal ini membuat Galeri Investasi Bursa Efek Indonesia di STIESIA Surabaya melakukan adanya literasi saham dengan menggandeng peran Perpustakaan STIESIA Surabaya. Kegiatan tersebut merupakan suatu kegiatan Perpustakaan yang bekerja sama dengan unit 
lainnya, yang belum pernah dilakukan di Galeri Bursa Efek Indonesia di tempat lain. Diharapkan dengan adanya literasi saham tersebut mampu menambah kesejahteraan investor, dimana dalam hal ini adalah mahasiswa.

\section{DAFTAR PUSTAKA}

Besley, Timothy. 2002. Economics and Public Choice. London: School of Economics and Political Science.
Darmadji, T. dan H. M. Fakhruddin. 2011. Pasar Modal di Indonesia: Pendekatan Tanya Jawab. Edisi Ketiga. Salemba Empat. Jakarta. https://dosenekonomi.com/ bisnis/investasi/keuntungan-investasi-saham. Diakses pada 24 Mei 2018.

Sunariyah. 2011. Pengantar Pengetahuan Pasar Modal. Edisi Keenam. UPP STIM YKPN. Yogyakarta. Understandings of Literacy. Diakses melalui http:// www. unesco.org/ education/GMR2006/full/ chapt6 eng.pdf pada 18 Mei 2018. 